\begin{tabular}{|c|c|c|}
\hline & Int.J.Curr.Microbiol.App.Sci (2021) 10(10): 350-362 & \\
\hline$\frac{}{\text { EXCELLENT }}$ & $\begin{array}{l}\text { International Journal of Current Microbiology and Applied Sciences } \\
\text { ISSN: 2319-7706 Volume } \mathbf{1 0} \text { Number } \mathbf{1 0}(\mathbf{2 0 2 1 )} \\
\text { Journal homepage: http://www.ijcmas.com }\end{array}$ & 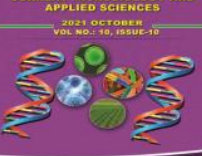 \\
\hline PUBLISHERS & & wwwijcmas.com \\
\hline
\end{tabular}

Original Research Article

https://doi.org/10.20546/ijcmas.2021.1010.043

\title{
Effect of Mulch and Nutrients on Yield and Physiological Parameters in Transplanted Ginger
}

\author{
Sandra Merin Mathew and G. S. Sreekala* \\ Department of Plantation crops and spices, College of Agriculture, \\ Vellayani, Thiruvanthapuram - 695522, India \\ *Corresponding author
}

\section{A B S T R A C T}

\section{Keywords}

Fertilizer, Ginger, Mulch, Rhizome bits, Transplanted

Article Info

Accepted: 15 September 2021 Available Online: 10 October 2021
The conventional propagation method using ginger rhizome being slow, a suitable method of raising ginger seed material in portrays has been devised by Indian Institute of Spices Research. The advantages of this technology are production of healthy uniform planting materials and reduction in seed rhizome quantity which eventually reduced cost on rhizomes. The experiment was carried out in the Instructional Farm, College of Agriculture, Vellayani during April 2016 to January 2017. The ginger variety used was Karthika. Field experiment was laid out in split plot design with four levels of mulches in main plots and fertilizer levels in sub plots with four replications.. Two nodded rhizome bits of ginger cultivar was raised in protrays were transplanted at 55 days in beds taken in the interspaces of coconut. Plants that received $\mathrm{M}_{1}$ (30 t ha $\left.{ }^{-1}\right)$ in main plot resulted in maximum plant height, number of tillers, number of leaves/plant and shoot weight, treatment $T_{2}\left(150: 100: 100 \mathrm{~kg} \mathrm{ha}^{-1}\right)$ and their interaction $\left(\mathrm{m}_{1} \mathrm{t}_{2}\right)$ also resulted in highest plant height, number of tillers, number of leaves/plant, shoot weight, Fresh yield and Dry yield on all periods of observation The results of the study indicated that ginger transplants intercropped in coconut garden, that mulching@30 t ha ${ }^{-1}$ (half at transplanting and half 2 MAT) along with 150:100:100 kg NPK ha ${ }^{-1}$ and basal application of $30 \mathrm{tha}^{-1}$ of farm yard manure could be recommended for higher yield and growth.

\section{Introduction}

Ginger (Zingiber officinale Rosc) is one of the earliest known oriental spices of the family Zingiberaceae is cultivated in India for underground modified stem called rhizomes which is used both as fresh vegetable and as a dried spice, since time immemorial. Ginger is mainly used as spice and flavoring agent in a wide variety of foods. India is the leading producer of ginger in the world producing $1025110 \mathrm{t}$ (Spices Board, 2016). In conventional planting, the seed rhizome of 1500 to $2500 \mathrm{~kg} / \mathrm{ha}$ is used depending on seed size and spacing. The conventional propagation methods of rhizomes being slow, a suitable method of raising ginger seed material in portrays has been devised by 
Indian Institute of Spices Research. Apart from the conventional method, this technique has been found to be cost effective and on par in yield. The advantages of this technology are production of healthy uniform planting materials and reduction in seed rhizome quantity which eventually reduced cost on seeds. In the view of this, the present experiment was conducted to see the effect of mulch and fertilizer in transplanted ginger.

\section{Materials and Methods}

The experiment was carried out in the Instructional Farm, College of Agriculture, Vellayani during April 2016 to January 2017. The ginger variety used was Karthika. Field experiment was laid out in split plot design with four levels of mulches $\left(M_{1}, M_{2}, M_{3}, M_{4}\right)$ in main plots and fertilizer levels in sub plots with four replications and plot size of $6 \mathrm{~m} \mathrm{X}$ $1 \mathrm{~m}$. The levels of mulches included organic mulches (mango leaves) @ 30, 15, and $7.5 \mathrm{t}$ ha ${ }^{-1}\left(\mathrm{M}_{1}, \mathrm{M}_{2}, \mathrm{M}_{3}\right.$ respectively $)$ and black coloured plastic mulch $\left(\mathrm{M}_{4}\right)$. For $\mathrm{M}_{1}$ and $\mathrm{M}_{2}$, half the quantity of organic mulch was applied at the time of transplanting (after 55 days) and the remaining at two months after transplanting (MAT). For $\mathrm{M}_{3}$, full quantity of mulch was applied at the time of transplanting. The sub plot treatments were $T_{1}(75: 50: 50 \mathrm{~kg}$ of NPK ha $\left.{ }^{-1}\right), \mathrm{T}_{2}$ (150: 100: $\left.100 \mathrm{~kg} \mathrm{ha}^{-1}\right), \mathrm{T}_{3}\left(\mathrm{~T}_{1}\right.$ + foliar application of 19:19:19 @ $0.5 \%$ applied at 1, 3, 4 MAT and $\mathrm{T}_{4}(100: 75: 75 \mathrm{~kg}$ $\mathrm{ha}^{-1}+$ foliar application of 19:19:19@0.5\% applied at 1, 3, 4 MAT). Two nodded rhizome bits of ginger cultivar was raised in protrays filled with Trichoderma enriched coir pith compost and FYM in the ratio $2: 1$ for treatments and were transplanted at 55days in beds taken in the interspaces of coconut. FYM @ $30 \mathrm{t} \mathrm{ha}^{-1}$ was applied uniformly to all plots. The plants are planted at spacing of $25 \mathrm{Cm} \mathrm{X}$ $25 \mathrm{Cm}$. . The observations were taken at bimonthly intervals (4MAP) from each plot maintained for observation and the mean was worked out. The fresh rhizome yield of five plants uprooted from plots maintained for destructive sampling was recorded at biomonthly intervals from 4 MAP and expressed in $\mathrm{kg} \mathrm{ha}^{-1}$. Dry ginger yield was recorded from five ginger plants harvested from plants maintained for destructive sampling at bimonthly intervals from 4 MAP. The fresh rhizomes were washed and kept in hot air oven at $70^{\circ} \pm 5^{\circ} \mathrm{C}$ till constant weight was obtained and at harvest dry ginger was measured from net plot and expressed in $\mathrm{kg}$ $\mathrm{ha}^{-1}$. Observation on dry matter production, Crop growth rate, Leaf area index and Chlorophyll content were made from plants maintained for destructive sampling at 4, 6 and 8 MAP

\section{Results and Discussion}

\section{Fresh yield}

The main plot treatment using mulch $\mathrm{M}_{1} @ 30$ $\mathrm{t} \mathrm{ha}^{-1}$ recorded the highest fresh yield on all periods of observation and resulted in $18093.53 \mathrm{~kg} \mathrm{ha}^{-1}$ in $8^{\text {th }}$ month (Table 1). This was followed by plots treated with plastic mulch $\left(\mathrm{M}_{4}\right)$ which recorded $17567.25 \mathrm{~kg} / \mathrm{ha}$. Fresh rhizome yield of ginger increased significantly as compared to no mulch in ginger (Chandra and Govind, 2001). Junior et al., (2005) reported that in turmeric maximum yield plant ${ }^{-1}$ was recorded in paddy straw mulched plots which was significantly superior to control. Yield of turmeric was maximum with the paddy straw mulch gave maximum yield (169.33 $\mathrm{q} \mathrm{ha}^{-1}$ ) followed by mulching with dry grass (131.33 q/ha) (Verma and Sarnaik, 2006).

Mahey et al., (1986) reported that application of paddy husk and wheat straw mulch increased the rhizome yield of turmeric by 59.5 and $218 \%$ as compared to no-mulch plots, respectively, due to improved weed control and augmented soil moisture retention 
through reduced evaporation. Better performance of the ginger in the beds treated with $30 \mathrm{t} \mathrm{ha}^{-1}$ of organic mulch might be due to the optimized soil temperature, controlled evaporation losses, increased soil moisture conservation, suppression of weeds and higher uptake of major, secondary and minor nutrients

Treatment $T_{2}$ recorded the highest fresh yield on all periods and obtained $17855.03 \mathrm{~kg} \mathrm{ha}^{-1}$ at harvest followed by $\mathrm{T}_{4}(17455.58 \mathrm{~kg} / \mathrm{ha}) \mathrm{T}_{3}$ and $\mathrm{T}_{1}$. Similar findings have been reported by Ajithkumar and Jayachandran (2001) that enhanced nitrogen application from $75 \mathrm{~kg} \mathrm{ha}^{-1}$ to $150 \mathrm{~kg} \mathrm{ha}^{-1}$ increased rhizome yield to 290 $\mathrm{kg} \mathrm{ha} \mathrm{h}^{-1}$ and application of phosphorus significantly increased the rhizome yield and enhanced $\mathrm{P}$ application, from $50 \mathrm{~kg} \mathrm{ha}^{-1}$ to 100 $\mathrm{kg} \mathrm{ha}^{-1}$ increased rhizome yield to $202 \mathrm{~kg} \mathrm{ha}^{-1}$. Satyareddi and Angadi (2014) showed higher fresh rhizomes yield per plot $\left(34.45 \mathrm{~kg} \mathrm{plot}^{-1}\right)$ and yield per ha $\left(23.41 \mathrm{t} \mathrm{ha}^{-1}\right)$ with application of $270: 135: 180 \mathrm{~kg} \mathrm{~N}: \mathrm{P}_{2} \mathrm{O}_{5}: \mathrm{K}_{2} \mathrm{O}$ ha ${ }^{-}$ 1 over other fertilizer levels in ginger.

The higher application of NPK (150:100:100 $\mathrm{kg} \mathrm{ha}^{-1}$ ) have resulted in higher uptake of NPK which might have contributed to higher rhizome yield compared to other nutrient levels.

Among interactions, combination of mulches @ $30 \mathrm{t} \mathrm{ha}^{-1}$ and double the recommended dose of fertilizer as per KAU package of practices $\left(\mathrm{m}_{1} \mathrm{t}_{2}\right)$ gave the highest yield on all periods of observation and recorded $18.64 \mathrm{t} \mathrm{ha}^{-1}$ in $8^{\text {th }}$ month followed by $\mathrm{m}_{4} \mathrm{t}_{2}\left(18135.30 \mathrm{~kg} \mathrm{ha}^{-1}\right)$ which was on par with $\mathrm{m}_{1} \mathrm{t}_{4}, \mathrm{~m}_{1} \mathrm{t}_{3}$ and $\mathrm{m}_{4} \mathrm{t}_{4}$.

The increase in plant height, number of leaves plant $^{-1}$, number of tillers plant ${ }^{-1}$, dry matter production, net assimilation rate due to higher uptake of NPK at increasing levels of mulches and fertilizer might have contributed to the increase in yield in $\mathrm{m}_{1} \mathrm{t}_{2}$

\section{Dry yield}

The treatment $\mathrm{M}_{1}$ mulching with@30 $\mathrm{tha}^{-1}$ recorded highest dry yield on different stages of observation and recorded $3828.15 \mathrm{~kg} \mathrm{ha}^{-1}$ during harvest. The dry ginger yield in plastic mulch treatment was $3564.38 \mathrm{t} \mathrm{ha}^{-1}$ (Table 2). The higher dry ginger yield $\mathrm{m}_{1} \mathrm{t}_{2}$ might be due to the higher nutrient (NPK) uptake as well as better soil conditions provided by highest quantity of mulch $\left(30 \mathrm{t} \mathrm{ha}^{-1}\right)$. Babu and Jayachandran (1997) reported that dry ginger yield showed an increasing trend with increasing levels of mulch and a significant yield reduction was noticed in ginger cultivated under open condition when the quantity of mulch was reduced from 30 to $22.5 \mathrm{t} / \mathrm{ha}$. Among the different mulching materials, dry leaves used as mulching material showed increased yield in ginger as reported by Sengupta et al., (2008). The yield performance of ginger varieties under open and oil palm plantations in Nigeria revealed that mulching is required under both conditions for increased yield (Nwaogu et al., 2011)

In subplot, treatments showed significant difference throughout the periods of observation and treatment $T_{2}$ recorded highest dry yield on all periods and obtained $3.91 \mathrm{tha}$ ${ }^{1}$ at harvest. The dry ginger yield of $\mathrm{T}_{4}$ was $3.58 \mathrm{t} \mathrm{ha}^{-1}$ while that for $\mathrm{T}_{3}$ and $\mathrm{T}_{1}$ were 3406.73 and $3319.73 \mathrm{~kg} \mathrm{ha}^{-1}$ respectively. Govind et al., (1995) reported that more secondary rhizomes per plant, and higher dry yields of rhizome in $\mathrm{cv}$. Nadia with $90 \mathrm{~kg}$ of $\mathrm{P}_{2} \mathrm{O}_{5} \mathrm{ha}^{-1}$.

Interaction effects were significant throughout the periods of observation and among interaction combination of mulches@30 t ha 1 and double the recommended dose of fertilizer as per KAU package of practice $\left(\mathrm{m}_{1} \mathrm{t}_{2}\right)$ obtained highest dry yield on all periods of observation and recorded $4316.10 \mathrm{~kg} \mathrm{ha}^{-1}$ at 
harvest followed by $\mathrm{m}_{4} \mathrm{t}_{2}\left(3881.80 \mathrm{~kg} \mathrm{ha}^{-1}\right)$ which was on par with $\mathrm{m}_{1} \mathrm{t}_{4}\left(3842.10 \mathrm{~kg} \mathrm{ha}^{-1}\right)$.

\section{Dry matter production}

Dry matter production was significant on main plot treatment of mulches, subplot treatment with different levels of fertilizers and their interaction (Table 3)

Treatment $\mathrm{M}_{1}$ with mulches @ $30 \mathrm{t} \mathrm{ha}^{-1}$ recorded highest dry matter production on all periods and obtained $76.95 \mathrm{~g}$ plant $^{-1}$ in $8^{\text {th }}$ month. Singh et al., (2014) reported that mulching with oak leaves in ginger resulted in maximum average soil moisture conservation $(54.5 \%)$ and with less average soil temperature $\left(20.4^{\circ} \mathrm{C}\right)$ and thus favoured yield.

In the present study also higher mulch the mulch (30 $\left.\mathrm{t} \mathrm{ha}^{-1}\right)$ might have helped in retaining more soil moisture as well as reducing soil temperature thus favouring good growth resulting in higher dry matter production.

Double the dose of recommended fertilizers recorded the highest dry matter production on all periods and obtained $75.67 \mathrm{~g} \mathrm{plant}^{-1}$ on $8^{\text {th }}$ month. This was similar to the results obtained by Mridula (1997) in mango-ginger that higher dose of $\mathrm{N}$ produced higher DMP. This shows that the supply of nutrients might have activated many metabolic processes leading to production of complex substances which in turn influenced the growth and yield of mango ginger.

Interaction effects were significant throughout the periods and among interaction combination of mulches @ $30 \mathrm{t} \mathrm{ha}^{-1}$ and double the recommended dose of fertilizer as per package of practices of KAU obtained the highest dry matter production on all periods of observation and recorded $83.70 \mathrm{~g} \mathrm{plant}^{-1}$ at $8^{\text {th }}$ month. The congenial conditions provided by mulch together with the higher nutrient combination $\left(\mathrm{m}_{1} \mathrm{t}_{2}\right)$ might have resulted in higher dry matter production.

\section{Crop growth rate}

Significant effects on crop growth rate (CGR) was observed at different periods of observation due to mulching, fertilizers and their combination.

Main plot treatment of mulching was significant only in period of $6^{\text {th }}$ to $8^{\text {th }}$ month and produced highest CGR in mulching @ 30 $\mathrm{t} \mathrm{ha}^{-1}$ and plastic mulch $\left(0.029 \mathrm{~g} \mathrm{~m}^{-2} \mathrm{day}^{-2}\right)$. Babu (1993) reported an increasing trend in CGR with increasing levels of mulch and also observed that under open condition mulching @ $22.5 \mathrm{t} \mathrm{ha}^{-1}$ and was on par with mulches @ $30 \mathrm{t} \mathrm{ha}^{-1}$.

In sub plot, fertilizer treatment were significant only in $4^{\text {th }}$ to $6^{\text {th }}$ months of observation and highest was recorded by NPK dose of 150:100:100 kg ha ${ }^{-1}$ and 100:75:75 kg ha ${ }^{-1}$ and foliar application of 19:19:19 @ $0.5 \% \quad\left(\mathrm{~T}_{4}\right)$.Maximum $\mathrm{CGR}$ and increased response to nutrients in terms of CGR under 25 and 50 per cent shade levels were observed by Joseph (1992) and Babu (1993) in ginger. Ajithkumar (1999) reported that a significant increase in CGR at higher levels of potassium $\left(100 \mathrm{~kg} \mathrm{~K}_{2} \mathrm{O}\right)$ at the later stages.

Interaction was significant during the periods of $4^{\text {th }}$ to $6^{\text {th }}$ months of observation and treatment combination of mulches @ $30 \mathrm{t} \mathrm{ha}^{-1}$ and fertilizer dose of 150:100:100 kg ha ${ }^{-1}$ noted the highest CGR on $4^{\text {th }}$ to $6^{\text {th }}$ months of observation

A significant difference was observed between the treatments and the control on all periods of growth. The comparison of $\mathrm{C}_{1}$ and $\mathrm{C}_{2}$ also showed a significant difference between them in $4^{\text {th }}$ to $6^{\text {th }}$ months. 
Table.1 Effect of mulches and nutrients on Fresh Yield $\left(\mathrm{kg} \mathrm{ha}^{-1}\right)$

\begin{tabular}{|c|c|c|c|}
\hline Treatments & $4^{\text {th }}$ month & $6^{\text {th }}$ month & Harvest \\
\hline (Mulches) $M_{1}$ & 5435.78 & 10574.03 & 18093.53 \\
\hline $\mathbf{M}_{2}$ & 4675.43 & 10011.45 & 17241.15 \\
\hline$M_{3}$ & 4053.15 & 9197.775 & 16385.18 \\
\hline$M_{4}$ & 5234.23 & 9958.80 & 17567.25 \\
\hline CD & 154.027 & 153.580 & 175.023 \\
\hline (Fertilizers) $T_{1}$ & 4501.65 & 9512.55 & 16746.15 \\
\hline $\mathbf{T}_{2}$ & 5241.23 & 10195.88 & 17855.03 \\
\hline $\mathbf{T}_{3}$ & 4660.95 & 9907.05 & 17230.35 \\
\hline $\mathbf{T}_{4}$ & 5082.75 & 10026.58 & 17455.58 \\
\hline CD & 156.37 & 167.364 & 121.861 \\
\hline (Interaction) $m_{1} t_{1}$ & 4902.00 & 10181.10 & 17545.80 \\
\hline $\mathrm{m}_{1} \mathbf{t}_{2}$ & 6120.90 & 10537.20 & 18644.40 \\
\hline$m_{1} t_{3}$ & 5187.60 & 10118.20 & 18045.30 \\
\hline$m_{1} t_{4}$ & 5532.60 & 10159.60 & 18138.60 \\
\hline$m_{2} t_{1}$ & 4473.60 & 9606.60 & 16756.80 \\
\hline$m_{2} t_{2}$ & 4969.80 & 10193.00 & 17717.10 \\
\hline$m_{2} t_{3}$ & 4537.50 & 9923.40 & 17196.90 \\
\hline $\mathbf{m}_{2} \mathbf{t}_{4}$ & 4720.80 & 10162.80 & 17293.80 \\
\hline$m_{3} t_{1}$ & 3728.70 & 8687.40 & 15931.80 \\
\hline$m_{3} t_{2}$ & 4246.20 & 9685.50 & 16923.30 \\
\hline$m_{3} t_{3}$ & 3906.00 & 9127.50 & 16208.70 \\
\hline $\mathbf{m}_{3} \mathbf{t}_{4}$ & 4331.70 & 9290.70 & 16476.90 \\
\hline$m_{4} t_{1}$ & 4902.30 & 9575.10 & 16750.20 \\
\hline$m_{4} t_{2}$ & 5628.00 & 10201.80 & 18135.30 \\
\hline$m_{4} t_{3}$ & 5012.70 & 9959.10 & 17377.20 \\
\hline$m_{4} t_{4}$ & 5793.90 & 10093.20 & 18006.30 \\
\hline CD & 312.729 & 334.729 & 257.722 \\
\hline
\end{tabular}


Table.2 Effect of mulches and nutrients on Dry yield $\left(\mathrm{kg} \mathrm{ha}^{-1}\right)$

\begin{tabular}{|c|c|c|c|}
\hline Treatments & $4^{\text {th }}$ month & $6^{\text {th }}$ month & Harvest \\
\hline (Mulches) $M_{1}$ & 1024.58 & 2172.60 & 3828.15 \\
\hline $\mathbf{M}_{2}$ & 821.78 & 1910.93 & 3504.75 \\
\hline $\mathbf{M}_{3}$ & 729.45 & 1757.93 & 3328.05 \\
\hline $\mathbf{M}_{4}$ & 961.88 & 1867.50 & 3564.38 \\
\hline CD & 27.525 & 35.941 & 44.317 \\
\hline (Fertilizers) $T_{1}$ & 765.68 & 1746.15 & 3319.73 \\
\hline $\mathbf{T}_{2}$ & 1013.25 & 2120.78 & 3911.10 \\
\hline $\mathbf{T}_{3}$ & 815.03 & 1879.95 & 3406.73 \\
\hline $\mathbf{T}_{4}$ & 943.73 & 1962.08 & 3587.78 \\
\hline CD & 24.736 & 25.169 & 35.806 \\
\hline (Interaction) $m_{1} t_{1}$ & 863.10 & 1990.20 & 3640.50 \\
\hline $\mathrm{m}_{1} \mathrm{t}_{2}$ & 1286.40 & 2489.40 & 4316.10 \\
\hline$m_{1} t_{3}$ & 919.80 & 1995.90 & 3513.90 \\
\hline$m_{1} t_{4}$ & 1029.00 & 2214.90 & 3842.10 \\
\hline$m_{2} t_{1}$ & 733.50 & 1722.60 & 3257.40 \\
\hline$m_{2} t_{2}$ & 971.10 & 2180.40 & 3811.10 \\
\hline$m_{2} t_{3}$ & 750.90 & 1800.30 & 3299.10 \\
\hline $\mathbf{m}_{2} \mathbf{t}_{4}$ & 831.60 & 1940.40 & 3581.40 \\
\hline$m_{3} t_{1}$ & 614.40 & 1517.40 & 3096.00 \\
\hline$m_{3} t_{2}$ & 830.10 & 2002.80 & 3635.40 \\
\hline$m_{3} t_{3}$ & 672.30 & 1707.30 & 3164.70 \\
\hline$m_{3} t_{4}$ & 801.00 & 1804.20 & 3416.10 \\
\hline$m_{4} t_{1}$ & 851.70 & 1754.40 & 3285.00 \\
\hline$m_{4} t_{2}$ & 965.40 & 1810.50 & 3881.80 \\
\hline$m_{4} t_{3}$ & 917.10 & 2016.30 & 3649.20 \\
\hline$m_{4} t_{4}$ & 1113.30 & 1888.80 & 3511.50 \\
\hline CD & 49.473 & 50.329 & 71.612 \\
\hline
\end{tabular}


Table.3 Effect of mulches and nutrients on Dry matter production (g plant $\left.{ }^{-1}\right)$

\begin{tabular}{|c|c|c|c|}
\hline Treatments & $4^{\text {th }}$ month & $6^{\text {th }}$ month & $8^{\text {th }}$ month \\
\hline (Mulches) $M_{1}$ & 31.80 & 48.79 & 76.95 \\
\hline $\mathbf{M}_{2}$ & 30.20 & 44.67 & 71.07 \\
\hline$M_{3}$ & 26.54 & 42.88 & 67.72 \\
\hline$M_{4}$ & 31.05 & 46.28 & 73.58 \\
\hline CD & 0.646 & 0.963 & 0.536 \\
\hline (Fertilizers) $T_{1}$ & 26.79 & 42.86 & 68.27 \\
\hline $\mathbf{T}_{2}$ & 33.03 & 47.61 & 75.67 \\
\hline $\mathbf{T}_{3}$ & 29.45 & 46.09 & 71.69 \\
\hline $\mathbf{T}_{4}$ & 31.81 & 46.06 & 73.70 \\
\hline CD & 0.530 & 0.979 & 0.424 \\
\hline (Interaction) $m_{1} t_{1}$ & 28.70 & 46.01 & 74.47 \\
\hline $\mathrm{m}_{1} \mathrm{t}_{2}$ & 35.47 & 51.32 & 83.70 \\
\hline$m_{1} t_{3}$ & 30.32 & 48.41 & 74.16 \\
\hline$m_{1} t_{4}$ & 32.73 & 49.31 & 75.50 \\
\hline$m_{2} t_{1}$ & 25.34 & 43.08 & 67.27 \\
\hline$m_{2} t_{2}$ & 33.77 & 46.17 & 75.50 \\
\hline$m_{2} t_{3}$ & 29.74 & 42.88 & 68.85 \\
\hline $\mathbf{m}_{2} \mathbf{t}_{4}$ & 31.96 & 46.55 & 72.70 \\
\hline$m_{3} t_{1}$ & 23.67 & 39.67 & 62.91 \\
\hline$m_{3} t_{2}$ & 28.92 & 44.57 & 69.50 \\
\hline$m_{3} t_{3}$ & 25.83 & 42.33 & 67.58 \\
\hline $\mathbf{m}_{3} \mathbf{t}_{4}$ & 27.75 & 44.96 & 70.92 \\
\hline$m_{4} t_{1}$ & 29.48 & 42.70 & 68.43 \\
\hline$m_{4} t_{2}$ & 33.97 & 42.19 & 74.02 \\
\hline$m_{4} t_{3}$ & 31.95 & 49.13 & 76.19 \\
\hline $\mathbf{m}_{4} \mathbf{t}_{4}$ & 34.23 & 49.32 & 75.69 \\
\hline CD & 1.071 & 1.948 & 0.858 \\
\hline
\end{tabular}

* Significant at 5\% level 
Table.4 Effect of mulch and nutrients on crop growth rate $\left(\mathrm{g} \mathrm{m}^{-2} \mathrm{day}^{-1}\right)$

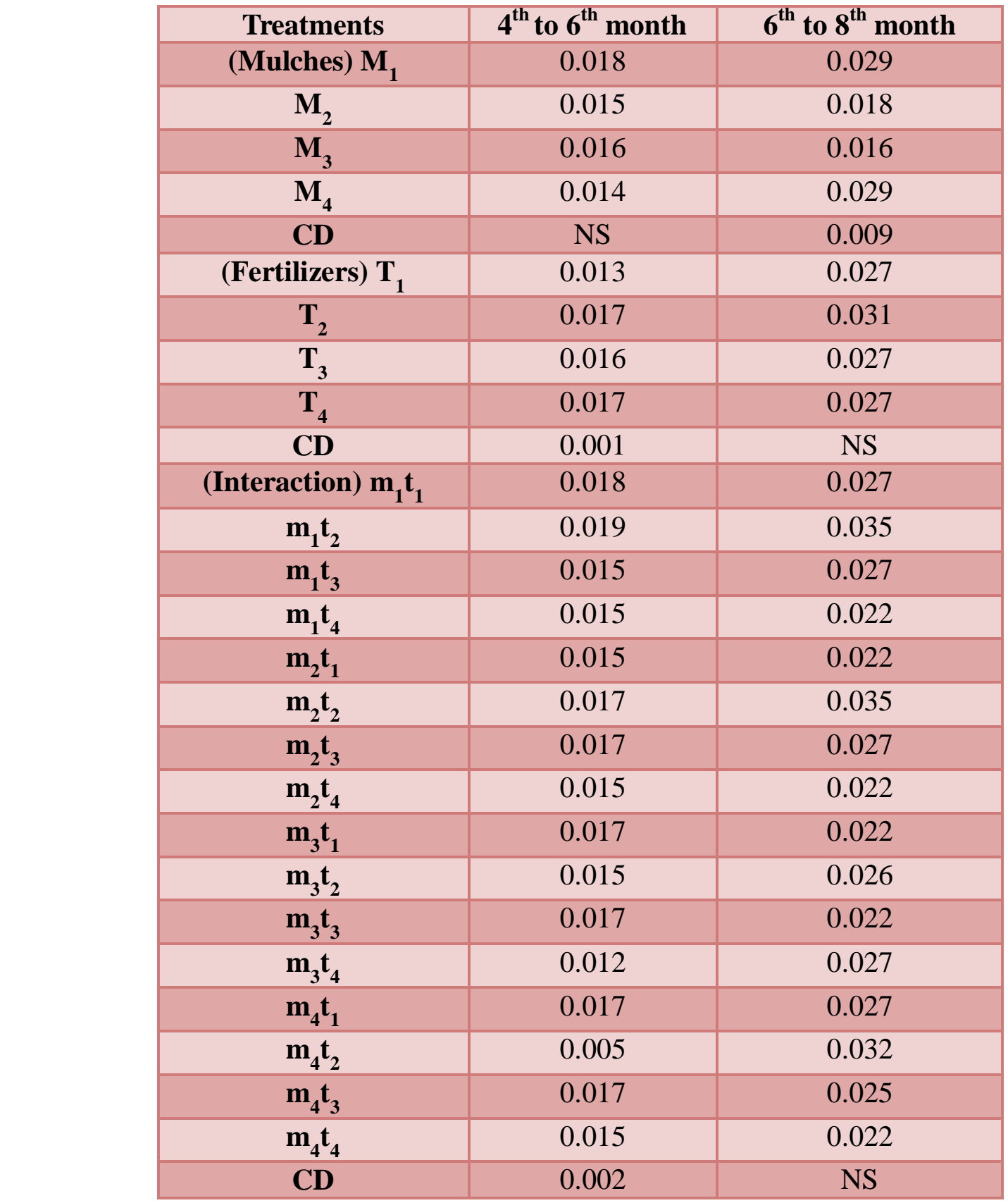


Table.5 Effect of mulch and nutrients on leaf area index

\begin{tabular}{|c|c|c|c|}
\hline Treatments & $4^{\text {th }}$ month & $6^{\text {th }}$ month & $8^{\text {th }}$ month \\
\hline (Mulches) $M_{1}$ & 7.33 & 8.38 & 8.64 \\
\hline $\mathbf{M}_{2}$ & 6.31 & 7.33 & 7.70 \\
\hline$M_{3}$ & 5.23 & 5.80 & 6.22 \\
\hline $\mathrm{M}_{4}$ & 6.63 & 6.96 & 7.42 \\
\hline CD & 0.205 & 0.132 & 0.061 \\
\hline (Fertilizers) $T_{1}$ & 5.68 & 6.42 & 6.77 \\
\hline $\mathbf{T}_{2}$ & 7.04 & 7.72 & 8.11 \\
\hline $\mathbf{T}_{3}$ & 6.19 & 6.92 & 7.30 \\
\hline $\mathbf{T}_{4}$ & 6.58 & 7.41 & 7.80 \\
\hline CD & 0.170 & 0.111 & 0.063 \\
\hline (Interaction) $m_{1} t_{1}$ & 6.42 & 7.68 & 8.00 \\
\hline $\mathbf{m}_{1} \mathbf{t}_{2}$ & 8.31 & 8.92 & 9.20 \\
\hline$m_{1} t_{3}$ & 7.02 & 8.32 & 8.56 \\
\hline$m_{1} t_{4}$ & 7.56 & 8.60 & 8.80 \\
\hline$m_{2} t_{1}$ & 5.30 & 6.39 & 6.72 \\
\hline$m_{2} t_{2}$ & 7.31 & 8.00 & 8.32 \\
\hline$m_{2} t_{3}$ & 6.23 & 7.01 & 7.52 \\
\hline $\mathbf{m}_{2} \mathbf{t}_{4}$ & 6.39 & 7.93 & 8.24 \\
\hline$m_{3} t_{1}$ & 4.91 & 5.33 & 5.81 \\
\hline $\mathbf{m}_{3} \mathbf{t}_{2}$ & 5.66 & 6.47 & 6.90 \\
\hline$m_{3} t_{3}$ & 5.01 & 5.60 & 5.92 \\
\hline $\mathbf{m}_{3} \mathbf{t}_{4}$ & 5.35 & 5.82 & 6.24 \\
\hline $\mathbf{m}_{4} \mathbf{t}_{1}$ & 6.07 & 6.28 & 6.56 \\
\hline$m_{4} t_{2}$ & 6.89 & 7.48 & 8.01 \\
\hline$m_{4} t_{3}$ & 6.51 & 6.78 & 7.20 \\
\hline $\mathbf{m}_{4} \mathbf{t}_{4}$ & 7.03 & 7.31 & 7.90 \\
\hline CD & 0.350 & 0.223 & 0.137 \\
\hline
\end{tabular}

* Significant at $5 \%$ level 
Table.6 Effect of mulch and nutrients on chlorophyll content $\left(\mathrm{mg} \mathrm{g}^{-1}\right)$

\begin{tabular}{|c|c|c|c|}
\hline Treatments & $4^{\text {th }}$ month & $6^{\text {th }}$ month & $8^{\text {th }}$ month \\
\hline (Mulches) $M_{1}$ & 0.52 & 0.86 & 1.33 \\
\hline $\mathrm{M}_{2}$ & 0.51 & 0.81 & 1.18 \\
\hline $\mathbf{M}_{3}$ & 0.43 & 0.82 & 1.16 \\
\hline $\mathbf{M}_{4}$ & 0.49 & 0.83 & 1.20 \\
\hline CD & 0.016 & 0.006 & 0.016 \\
\hline (Fertilizers) $T_{1}$ & 0.47 & 0.79 & 1.18 \\
\hline $\mathbf{T}_{2}$ & 0.51 & 0.85 & 1.24 \\
\hline $\mathbf{T}_{3}$ & 0.49 & 0.83 & 1.22 \\
\hline $\mathbf{T}_{4}$ & 0.49 & 0.82 & 1.24 \\
\hline CD & 0.013 & 0.003 & 0.008 \\
\hline (Interaction) $m_{1} t_{1}$ & 0.50 & 0.835 & 1.22 \\
\hline $\mathbf{m}_{1} \mathbf{t}_{2}$ & 0.54 & 0.91 & 1.39 \\
\hline $\mathrm{m}_{1} \mathrm{t}_{3}$ & 0.53 & 0.86 & 1.33 \\
\hline $\mathbf{m}_{1} \mathbf{t}_{4}$ & 0.52 & 0.87 & 1.37 \\
\hline $\mathbf{m}_{2} \mathbf{t}_{1}$ & 0.51 & 0.77 & 1.18 \\
\hline $\mathbf{m}_{2} \mathbf{t}_{2}$ & 0.52 & 0.81 & 1.21 \\
\hline $\mathrm{m}_{2} \mathrm{t}_{3}$ & 0.50 & 0.84 & 1.19 \\
\hline $\mathbf{m}_{2} \mathbf{t}_{4}$ & 0.51 & 0.86 & 1.15 \\
\hline $\mathrm{m}_{3} \mathrm{t}_{1}$ & 0.42 & 0.79 & 1.10 \\
\hline $\mathrm{m}_{3} \mathrm{t}_{2}$ & 0.48 & 0.83 & 1.16 \\
\hline$m_{3} t_{3}$ & 0.43 & 0.82 & 1.17 \\
\hline$m_{3} t_{4}$ & 0.44 & 0.84 & 1.19 \\
\hline $\mathrm{m}_{4} \mathrm{t}_{1}$ & 0.46 & 0.79 & 1.18 \\
\hline $\mathbf{m}_{4} \mathbf{t}_{2}$ & 0.52 & 0.86 & 1.21 \\
\hline $\mathrm{m}_{4} \mathrm{t}_{3}$ & 0.49 & 0.85 & 1.22 \\
\hline$m_{4} t_{4}$ & 0.52 & 0.83 & 1.23 \\
\hline CD & 0.026 & 0.017 & 0.017 \\
\hline
\end{tabular}

** Significant at $1 \%$ level

The CGR also increased with the advancement of growth from $4^{\text {th }}$ to $6^{\text {th }}$ month and $6^{\text {th }}$ to $8^{\text {th }}$ month. For all the subplot treatment and interaction the CGR increased with the advancement in growth, but for the main plot treatment $\mathrm{M}_{2}$, CGR remained the same during $4^{\text {th }}$ to $6^{\text {th }}$ and $6^{\text {th }}$ to $8^{\text {th }}$ months. Thus mulching @ $30 \mathrm{t} \mathrm{ha}^{-1}$ and use of plastic mulch had shown a rapid growth during the period for $6^{\text {th }}$ to $8^{\text {th }}$ month, while other main plot treatments had shown a slow steady growth rate. The lower CGR during the early phase in $\mathrm{M}_{3}$ and $\mathrm{M}_{2}$ favoured more of weed growth and development ultimately affecting the growth and yield of the crop.

\section{Leaf area index}

Treatment with mulch treatment, fertilizer and their interaction had significant influence in 
the leaf area index (LAI) at all periods of growth and interaction effect is presented in

Application of $30 \mathrm{t} \mathrm{ha}^{-1}$ of mulch $\left(\mathrm{M}_{1}\right)$ retained significantly higher LAI in all periods of growth and recorded 8.64 at $8^{\text {th }}$ month. Under open and shade levels the application of higher quantities of mulch enhanced total leaf area (Babu, 1993). Ajithkumar (1999) reported no significant effect of mulch on leaf area.

In sub plot treatment double the recommended dose of fertilizer, $\mathrm{T}_{2}\left(150: 100: 100 \mathrm{~kg} \mathrm{ha}^{-1}\right)$ recorded the highest of 8.11 in $8^{\text {th }}$ month. Potassium is important in the photosynthetic process and it increases leaf area and carbon dioxide assimilation (Russell, 1973). Joseph (1992) observed an increase in LAI with increase in fertilizer level in ginger. Ajithkumar (1999) reported that higher LAI was observed with increase in fertilizer levels.

Interaction effect resulted in significant difference in all periods of growth and the highest LAI was recorded from the combination of mulches @ $30 \mathrm{t} \mathrm{ha}^{-1}$ and fertilizer dose of 150:100:100 kg ha ${ }^{-1}\left(\mathrm{~m}_{1} \mathrm{t}_{2}\right)$ in all periods of observation and in $8^{\text {th }}$ month LAI of 9.20 was recorded.

LAI of treatments varied significantly from the control on all periods of growth. The comparison of $\mathrm{C}_{1}$ as well as $\mathrm{C}_{2}$ with the treatments also indicated significant difference in the number of leaves in all periods of growth. A significant difference was noticed in LAI between the control $\mathrm{C}_{1}$ and $\mathrm{C}_{2}$. Mridula (1997) in mango ginger reported positive and significant correlation of LAI with yield. LAI is an important agronomic parameter which reflects crop growth and predicts crop yield (Fageria et al., 2006).Differences in leaf area can affect plant spatial distribution and the microenvironment within population (Giunta et al., 2008) which plays a decisive role in the photosynthetic efficiency and light energy distribution of crops (Boedhran et al., 2001; Elings, 2000). Higher LAI noticed is $\mathrm{M}_{1}, \mathrm{~T}_{2}$ and $\mathrm{m}_{1} \mathrm{t}_{2}$ might have helped in harvesting more light which together with more uptake of nutrients producing more photosynthates and translocated to rhizomes.

\section{Chlorophyll content}

Significant differences in chlorophyll content among mulch treatments was observed throughout the crop growth period. (Table 6)

Plants that received $30 \mathrm{t} \mathrm{ha}^{-1}$ of mulch $\left(\mathrm{M}_{1}\right)$ resulted in maximum chlorophyll content in all growth periods. At 8 months chlorophyll content of $1.33 \mathrm{mg} \mathrm{g}^{-1}$ was recorded from $\mathrm{M}_{1}$. The positive influence of mulch on chlorophyll content may be due to enhanced soil physical condition caused by the mulch treatment.

Sub plot treatment of 150:100:100 kg ha ${ }^{-1}\left(\mathrm{~T}_{2}\right)$ recorded the highest chlorophyll content on $4^{\text {th }}$ and $6^{\text {th }}$ months of observation. while in 8 months chlorophyll content of $1.24 \mathrm{mg} \mathrm{g}^{-1}$ was recorded for 150:100:100 kg ha ${ }^{-1}\left(\mathrm{~T}_{2}\right)$ and 100:75:75 kg ha ${ }^{-1}+$ foliar application of 19:19:19@0.5\% ( $\left.\mathrm{T}_{4}\right)$. Nitrogen is an integral part of chlorophyll molecule, thus its supply at higher amount would have favoured the production of chlorophyll which in turn increased photosynthetic efficiency of plant and thus yield. Higher nutrient levels were adequate for the production of good amount of chlorophyll.

The interaction between mulching and fertilizers, was significant throughout the periods of observation and combination of mulches@30 $\mathrm{t} \mathrm{ha}{ }^{-1}$ and fertilizer dose of 150:100:100 $\mathrm{kg} \mathrm{ha}^{-1}$ resulted in maximum chlorophyll content. The results of the study indicated that ginger transplants intercropped in coconut garden at 50-55 days mulched with 
@ $30 \mathrm{t} \mathrm{ha}^{-1}$ half of which applied at transplanting and half 2 MAT along with 150:100:100 kg NPK ha ${ }^{-1}$ and basal application of $30 \mathrm{t} \mathrm{ha}^{-1}$ of farm yard manure produced ginger plants with higher yield and physiological parameters.

\section{Acknowledgements}

The authors are grateful to the Instructional farm, College of Agriculture, Vellayani and Department of Plantation Crops and Spices, College of Agriculture, Vellayani

\section{References}

Abraham, E., John, J., and Pillai, S. P. 2016. Allelopathic effect of leaf loppings of homestead trees on ginger (Zingiber officinale Roscoe). J. Trop. Agri. 54 (1) : 60-65.

Agrawal, M., Walia, S., Dhingra, S., and Khambay, B. P. S. 2001. Insect growth inhibition antifeedant and antifungal activity of compounds isolated derived from ginger rhizome(Zingiber officinale Roscoe). Agric. Res. 41(2): 137-41.

Ajithkumar, K. 1999. Production dynamics of ginger (Zingiber officinale R.) under varying levels of shade, nutrients and triazole. Ph.D. thesis, Kerala Agricultural University, Thrissur, $274 p$.

Ajithkumar, K. and Jayachandran, B. K. 2001. Effect of major nutrients on yield of ginger (Zingiber officinale Rose.) intercropped in coconut garden. $J$. Spices Aromat. Crops. 10(1): 17-23.

Akinwumi,G. S., Fariyike, T. A., Olufunmi, O. O., Olabode, I. A., and Adelaja, B. A. 2013. Influence of the rate and timing of mulching on the growth and yield of ginger (Zingiber officinale L.). International J. Curr. Res. 8(2) :26548-26550.
Babu, P. 1993. Effect of shade and mulch on yield of ginger (Zingiber officinale R.). M.Sc.(Hort) thesis, Kerala Agricultural University, Thrissur, 80p.

Babu, P. and Jayachandran, B. K. 1997. Mulch requirement of ginger (Zingiber officinale Rosc.) under shade. J. Spices Aromat. Crops. 6(4): 141-143.

Boedhram, N., Arkebauer, T. J., and Batchelor, W. D. 2001. Season-long characterization of vertical distribution of leaf area in corn. Agron. J. 93: 1235-1242.

Chandra, R. and Govind, S. 2001. Effect of mulching on yield of ginger (Zingiber officinale Rosc.). J. Spices Aromat. Crops. 10 (1) : 13-16

Dayankatti, B. S. and Sulikeri, G. S. 2000. Effect of plant population and nitrogen levels of growth, yield and quality of ginger - growth attributes. Karnataka J. Agric. Sci. 13 (4): 1047-1048.

Elings, A. 2000. Estimation of leaf area in tropical maize. Agron. J. 2(5) : 436444.

Fageria, N. K., Baligar, V. C. and Clark. R. B. 2006. Root Architecture. In: Physiology of Crop Production. The Haworth Press, Binghamton, NY, USA. pp. 23-59.

Giunta, F., Motozo, R. and Pruneddu, G. 2008. Long term selection for yield in durum wheat also induced changes in leaf and canopy traits. Field crops Res. 106: 108-76.

Govind, S., Chandra, R., and Gupta, P. N. 1995. Response of ginger to $\mathrm{P}$ in acid alfisoil of Meghalaya. J. Hill Res. 8(3): 2 74-276.

Islam, M. A., Rahim, M. A., and Iqbal, T. M. T. 2015.Effect of irrigation and mulching on growth and yield of ginger. Bangladesh Agron. J. 18(1): 27-36

Joseph, A. 1992. Nutrient requirement of ginger under shade. M.Sc.(Hort) thesis, 
Kerala Agricultural University, Thrissur, 97p.

Junior, M. A., Borella, J. C., Franca, S. C., and Masca, M. G. C. C. 2005. Effects of type of rhizomes used to proliferation and mulching on growth and productivity of turmeric (Curcuma longa L.). Revista Brasileira Plantas Medi. 8(3) : 30-34.

Mahey, R. K., Randhawa, G. S., and Gill, S. R. S.1986. Effect of irrigation and mulching on water conservation, growth and yield of turmeric. Indian $J$. Agron. 31(2): 72-82.

Mridula, K. 1997. Nutrient requirement of mango- ginger. M.Sc.(Hort) thesis, Kerala Agricultural University, Thrissur, 87p.

Muralidharan, A., Varma, A. S., and Nair, E. V. G. 1974. Effect of nitrogen, phosphorus and potash on growth and yield of ginger (Zingiber officinale Rosc.). Indian J. Agron. 11(3): 102104.

Nwaogu, E. N., Nwosu, P. O., Ano, A. O., and Okonkwo, J. C. 2011. Effect of pigeon pea hedgerow alley management on the growth and productivity of ginger in a tropical Ultisol in South Eastern Nigeria. Annual Report, National Root Crops Research Institute, Umudike, 181p.

Pradeepkumar, T., Mayadevi, P., Aipe, K. C., Manomohandas, T. P., Giridharan, M. P., Satheesan, K. N., and Kumaran, K. 2001. Optimum dose of nitrogen and potassium for ginger (Zingiber officinale Rosc.) in Wynad, Kerala. $J$. Spices Aromat. Crops. 10(1): 7-11.

Russell, E.W. 1973. Soil Conditions and Plant Growth. Tenth Edition, Longman Group Lrd., London, p.634

Satyareddi, S. A. and Angadi, S. S. 2014. Response of turmeric (Curcuma longa L.) varieties to irrigation methods and graded levels of fertilizer. Res. Environ. Life Sci. 7(4): 237-242.

SB [Spices Board]. 2016. SB annual production of spice 2015-2016 [on line].

Available:http://www.spicesboard.org. [15 May.2017].

Sengupta, D. K., Maity, T. K., and Dasgupta, B. 2008.Effect of growth regulators on growth and rhizome production of ginger (Zingiber officinale Rosc.) in the hilly region of Darjeeling district. J. Crop Weed 4(3) : 10- 13.

Singh, A. K., Singh, R. K., Singh, A. K., Singh, V. K., Rawat, S. S., Mehta, K. S., Kumar, A., Gupta, M. K., and Thakur. S. 2014. Biomulching for ginger crop management : Traditional ecological knowledge led adaptation under rainfedd agroecosystems. Indian Journal of Traditional knowledge 13(1) : 111-122.

Verma, A. and Sarnaik, D. A. 2006. Effect of different types of mulches on growth and yield of turmeric (Curcuma longa L.). Internat. J. agric. Sci. 2(2):425426

\section{How to cite this article:}

Sandra Merin Mathew and Sreekala, G. S. 2021. Effect of Mulch and Nutrients on Yield and Physiological Parameters in Transplanted Ginger. Int.J.Curr.Microbiol.App.Sci. 10(10): 350362. doi: https://doi.org/10.20546/ijcmas.2021.1010.043 